\title{
Growth and persistence of perennial ryegrass lines with different tolerances to "pulling" during grazing
}

\author{
E.R. THOM, V.T. VAN VUGHT and R.J. McCABE \\ Dairying Research Corporation, Private Bag 3123, Hamilton
}

\begin{abstract}
The effects of ryegrass genotype, nitrogen $(\mathrm{N})$ fertiliser and soil type on the level of plant losses by "pulling" during grazings were studied over 2 years. Plots of high-endophyte pipeline perennial ryegrass lines, coded A1 and A3, were established on the Dairying Research Corporation No. 2 Dairy in May 1994. Three plots of each line were sown on a Te Kowhai silt loam and three on a Te Rapa peaty silt loam soil. Half the area of each plot received nitrogen fertiliser (30 kg N/ha) after grazings from September 1995 to February 1996. Line A1 pulled more than did A3. Pulling was worse on the peat than on the silt loam, and was highest during summer-autumn 1994-95, which included a prolonged dry spell. $\mathrm{N}$ fertiliser increased post-flowering tillering, especially for A1. A1 had a higher leaf shear strength $(6.21 \mathrm{vs}$ $5.91 \mathrm{~kg}, \mathrm{SED}=0.087)$ and a wider leaf $(3.40 \mathrm{vs}$ $3.22 \mathrm{~mm}, \mathrm{SED}=0.054)$ than A3. It is argued that these morphological differences were important contributors to the observed pulling differences. Since A1 outyielded A3, we consider that plant losses owing to pulling did not constitute a serious loss of herbage dry matter.
\end{abstract}

Keywords: dairying, leaf morphology, leaf shear strength, Lolium perenne, nitrogen fertiliser, persistence, pulling losses, tiller dynamics, tillering

\section{Introduction}

A perennial ryegrass (Lolium perenne L.) population located on a dairy farm at Mangere, South Auckland, has been the dominant genetic source for New Zealand-bred perennial ryegrass cultivars over the past 20 years. Cumberland \& Honore (1970) summarised early comparisons of the Mangere ecotype with Grasslands Ruanui and Grasslands Ariki ryegrasses, demonstrating the superior ability of the Mangere ecotype to persist through dry summers and to increase growth rapidly when autumn rain started. Natural selection for these characteristics was probably encouraged by the fertile but summer-dry volcanic ash soil on which the Mangere ecotype developed. Some examples of cultivars derived from the Mangere ecotype include Ellett, Grasslands Nui and Yatsyn I.

During recent testing of further selections from the Mangere ecotype at four Waikato sites, a wide range of tolerances to "pulling" or the physical removal of clumps of ryegrass plants (plus $2-5 \mathrm{~cm}$ of roots) from the sward by cows during grazing was noted, suggesting a genetic component to the ryegrass pulling phenomenon. Losses of grass plants or tillers have often been associated with cattle grazing in summer-autumn (Hughes \& Jackson 1974; Thom et al. 1986) and some researchers have correlated increased pulling with increased use of nitrogen $(\mathrm{N})$ fertiliser (Mitchell \& Dickens 1979; Tallowin et al. 1986). Many explanations of ryegrass pulling have appeared in the popular press (e.g., Anon 1992), but the relative importance of pulling to sward tiller density, herbage accumulation and persistence is not well defined for intensive dairying systems.

$\mathrm{N}$ fertiliser can increase tillering in perennial ryegrass, and regular $\mathrm{N}$ applications over late springearly summer may improve post-flowering tillering (Harris et al. 1996). This mechanism could be important for cultivars such as Ellett ryegrass, which may rely on post-flowering vegetative tillering from reproductive tiller bases for persistence (Matthew et al. 1993).

This paper describes some agronomic and morphological characteristics of two unnamed pipeline selections (coded A1 and A3) bred from the Mangere ecotype, and their responses to $\mathrm{N}$ fertiliser. These lines were chosen because previous observations suggested A1 was more susceptible to pulling than was A3. The study was carried out on different soil types since anecdotal evidence suggested ryegrass pulling was more common on peat than silt loam soils. The aim of the study was to identify possible differences between A1 and A3 that may provide further insights into the ryegrass persistence problem, and provide directions for plant breeding programmes.

\section{Methods and materials}

\section{Sites}

Six $(12 \times 4 \mathrm{~m})$ plots of high-endophyte ryegrass lines A1 and A3 were cross-drilled ( $7 \mathrm{~kg} / \mathrm{ha}$ each pass) in May 1994, where the pasture had been treated with $1.08 \mathrm{~kg}$ a.i./ha of glyphosate (Roundup herbicide, $36 \%$ 
glyphosate). Aran white clover (Trifolium repens L.) was drilled $(3 \mathrm{~kg} / \mathrm{ha})$ in a third pass. Three plots of each line were drilled on a Te Kowhai silt loam soil and three on a Te Rapa peaty silt loam (pale subsoil variant) on No. 2 Dairy. Singleton (1991) considered both soils have poorly drained subsoils with root penetration limited to $20 \mathrm{~cm}$ (topsoil) in the Te Kowhai and $70 \mathrm{~cm}$ in the Te Rapa.

\section{Trial design}

Plots of ryegrass lines were arranged in randomised blocks with 3 replicates on each soil type. A $\mathrm{N}$ fertiliser subplot treatment began in October 1995; $30 \mathrm{~kg} \mathrm{~N} / \mathrm{ha}$ (as urea) was applied on 7 occasions to half the area (6 $\times 4 \mathrm{~m}$ ) of each main plot, after grazings from October 1995 to February 1996 (Table 1).

Table 1 Timing of $\mathrm{N}$ fertiliser applications to the trial sites.

\begin{tabular}{|c|c|c|c|}
\hline \multicolumn{2}{|c|}{-------- Silt loam soil -------- } & \multicolumn{2}{|c|}{---- Peat soil - -- } \\
\hline Date & Rate (kg N/ha) & Date & Rate (kg N/ha) \\
\hline 4 Oct 1995 & 30 & 10 Oct 1995 & 30 \\
\hline 24 Oct & 30 & 30 Oct & 30 \\
\hline $14 \mathrm{Nov}$ & 30 & $21 \mathrm{Nov}$ & 30 \\
\hline $6 \mathrm{Dec}$ & 30 & $14 \mathrm{Dec}$ & 30 \\
\hline $31 \mathrm{Dec}$ & 30 & $31 \mathrm{Dec}$ & 30 \\
\hline 31 Jan 1996 & 30 & 31 Jan 1996 & 30 \\
\hline $20 \mathrm{Feb}$ & 30 & 20 Feb & 30 \\
\hline
\end{tabular}

\section{Grazing management}

Over 1994-95 the sites were intensively grazed by similar Friesian herds stocked at 3.2 cows/ha, increasing to $4.4 \mathrm{cows} / \mathrm{ha}$ from 1 June 1995 . Grazing rotations for both sites during summer-autumn 1995 ranged from 3 to 4 weeks, extending to 12 weeks over winter. The peat site was grazed every 2 weeks from mid-November to late-December 1995 compared with every 3 weeks for the site on mineral soil, extending to 3 to 4 weeks for both sites in summer-autumn 1996.

\section{Pasture measurements}

Two measurement periods are defined - Period 1: January-September 1995 and Period 2: October 1995April 1996, when the $\mathrm{N}$ fertiliser treatment was imposed.

During Period 1, herbage accumulation on main plots was estimated from 15 readings of a calibrated pasture probe before and after each grazing. When the $\mathrm{N}$ treatment began in Period 2, a similar procedure was carried out on a subplot basis.

Standard procedures (Thom et al. 1986) were used to determine the botanical composition of herbage collected from main plots in February, April and July 1995 (Period 1) and from subplots in September and December 1995, and March 1996 (Period 2).
Ryegrass and Poa spp. tiller densities were estimated on 3 occasions from tiller counts in 2 randomly positioned frames $(20 \times 5 \mathrm{~cm})$ per plot in Period 1, and in 2 frames per subplot in Period 2.

Immediately after grazings clumps of ryegrass plants pulled from the pasture by cows were counted in 2 randomly located $1 \mathrm{~m}^{2}$ frames in main plots during Period 1, and 1 frame per subplot in Period 2.

A Warner-Bratzler shear machine (Easton 1989) was used to estimate leaf shear strength. Five ryegrass clumps of similar size were removed from each subplot in April 1996. The youngest fully expanded leaf blade on 10 randomly selected tillers per clump was removed and formed into a bundle by aligning the ligule ends, providing the sample to be measured. Each bundle was shorn twice at about $3 \mathrm{~cm}$ from the ligules and again at about $6 \mathrm{~cm}$. The two $3-\mathrm{cm}$ leaf samples were weighed after drying.

The width of all leaves within each bundle was measured at $3-6 \mathrm{~cm}$ from the ligule end, before shearing, using a Vernier calliper accurate to within $0.05 \mathrm{~mm}$.

Three circular (63 $\mathrm{mm}$ diam.) fixed frames per subplot were located over ryegrass plants in September 1995 , for the study of tiller dynamics.

\section{Statistical analysis}

Analysis of variance was used to test for treatment differences at each measurement date using the statistical packages SAS and Genstat 5.3. Tiller density data were analysed after log transformation, but for ease of interpretation untransformed means are presented with error terms as the least significant ratio (LSR).

\section{Results}

\section{Climate}

The winter after establishment (June to August 1994) had 42 frosts $\left(<-1^{\circ} \mathrm{C}\right)$ compared with the longer-term average of 29. A wet September (164 $\mathrm{mm}$ or $67 \%$ above average rainfall) was followed by dry weather for 64 days from 23 November 1994 to 26 January 1995, when there was only $41 \mathrm{~mm}$ of rain on 13 days. Rainfalls in December 1994 and January 1995 were 74 and 21\% below average, respectively. Rainfall from March 1995 to April 1996 was equal to or above average, apart from January, which had only $57 \%$ of the average at $62 \mathrm{~mm}$. Winter 1995 had fewer frosts than average.

\section{Period 1 (January-September 1995)}

\section{Ryegrass pulling}

The number of pulled ryegrass clumps in A1 plots was consistently greater than in $\mathrm{A} 3$, reaching significance from February to April (Figures 1 and 2). Cumulative 
pulling was 2-3 times higher for A1 than for $\mathrm{A} 3$, and differences between lines were significant on the peat soil (44 vs 19 , SED $\left.=0.60^{* * *}\right)$. Counts of pulled ryegrass clumps were highest in summer-autumn and declined to a low level in winter (July). The highest level of pulling for both lines occurred on the peat soil (Figure 1).

Figure 1 The effect of line on pulling of clumps of ryegrass plants $\left(\right.$ pulls $\left./ \mathrm{m}^{2}\right)$ from peat soil during Period 1. Bars are LSD $(\mathrm{P}<0.05)$.

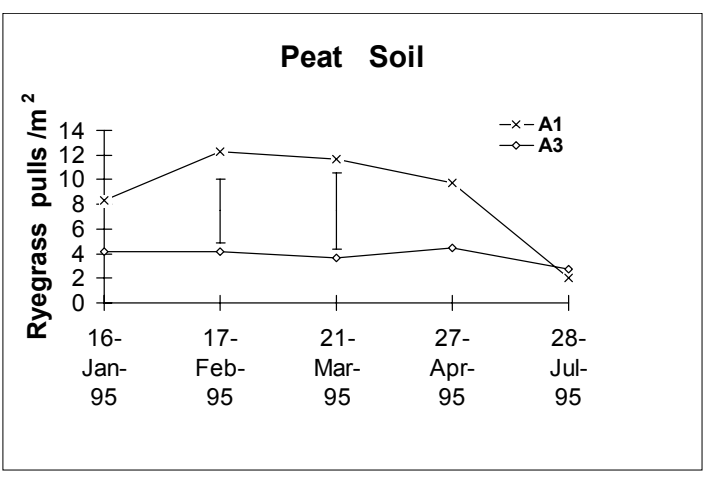

Figure 2 The effect of line on pulling of clumps of ryegrass plants $\left(\right.$ pulls $/ \mathrm{m}^{2}$ ) from silt loam soil during Period 1. Bar is LSD $(\mathrm{P}<0.05)$.

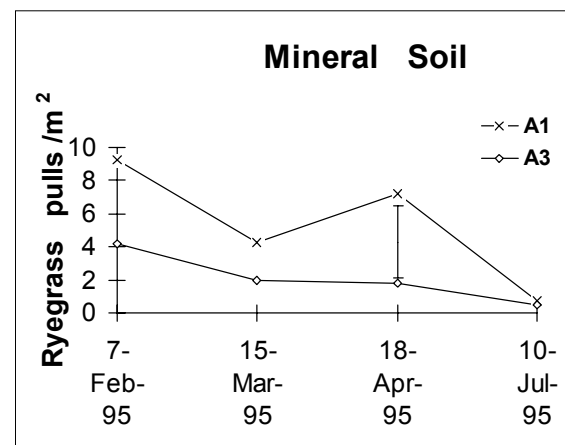

\section{Herbage accumulation}

In January and March 1995, A3 tended to be grazed more severely on the silt loam, reducing its regrowth compared with A1 (2474 vs $2715 \mathrm{~kg} \mathrm{DM} / \mathrm{ha})$. The pregrazing yield of $\mathrm{A} 1$ also exceeded that of $\mathrm{A} 3$ on the peat soil (3198 vs $2974 \mathrm{~kg} \mathrm{DM} / \mathrm{ha}$ ) and overall growth on A1 exceeded that of A3 (2956 vs 2724, SED = $30.8^{* *}$ ). Pre-grazing yields on the peat over summerautumn (January to April) for A1 always exceeded those for A3, with a maximum difference in April of $525 \mathrm{~kg} \mathrm{DM} /$ ha. However, total yield was not different on the silt loam (Table 2).
Table 2 Effect of soil type on total herbage accumulation ( $\mathrm{kg}$ $\mathrm{DM} / \mathrm{ha}$ ) over summer-autumn 1995 for ryegrass lines $\mathrm{A} 1$ and $\mathrm{A} 3$.

\begin{tabular}{lccc}
\hline Line & Peat & Silt loam & SED $^{\text {a }}$ \\
\hline A1 & 4435 & 3957 & $189^{*}$ \\
A3 & 3660 & 4068 & \\
\hline
\end{tabular}

a SED for comparison of interaction means

${ }^{*}=\mathrm{P}<0.05$

There were few significant treatment differences in pasture botanical composition or tiller density.

\section{Period 2 (October 1995-April 1996)}

\section{Ryegrass pulling}

Ryegrass pulling during the second summer-autumn was less than during the first. As for Period 1, pulling was higher on the peat soil than the silt loam; cumulative means were 23.8 and 11.2, respectively. Pulling on the silt loam soil did not exceed $2 / \mathrm{m}^{2}$, regardless of treatment, until February 1996. Although pulling was always greater on A1 than A3 plots, differences failed to reach significance except in December 1995, and cumulative differences did not reach significance until February 1996 (Table 3). Cumulative differences between $\mathrm{N}$-treated and untreated plots did not reach significance $\left(19.8\right.$ vs $\left.15.3 \mathrm{pulls} / \mathrm{m}^{2}, \mathrm{SED}=3.14{ }^{\mathrm{NS}}\right)$.

Table 3 Cumulative effect of line on ryegrass pulling $\left(\mathrm{pulls} / \mathrm{m}^{2}\right)$ during Period 2.

\begin{tabular}{lccc}
\hline Date & A1 & A3 & SED \\
\hline 1995 & & & \\
Sept & 2.3 & 1.1 & $1.02^{\mathrm{NS}}$ \\
Oct & 3.6 & 2.6 & $1.49^{\mathrm{NS}}$ \\
Early Nov & 5.9 & 3.9 & $1.70^{\mathrm{NS}}$ \\
Late Nov & 8.7 & 5.8 & $2.21^{\mathrm{NS}}$ \\
Dec & 13.9 & 7.9 & $2.25^{(\dagger)}$ \\
1996 & & & \\
Jan & 14.1 & 8.0 & $2.26^{(\dagger)}$ \\
Feb & 17.3 & 9.8 & $2.41^{*}$ \\
Mar & 22.8 & 12.3 & $2.40^{* *}$ \\
\hline
\end{tabular}

$\mathrm{NS}=$ not significant; $\left.{ }^{(}\right)=\mathrm{P}<0.10 ;{ }^{*}=\mathrm{P}<0.05 ;{ }^{* *}=\mathrm{P}<0.01$

\section{Herbage accumulation}

Plots were grazed to a similar level on both soil types, since there were no significant differences in postgrazing yields between lines, which averaged $1700 \mathrm{~kg}$ $\mathrm{DM} /$ ha. Pre-grazing yields were also similar for both lines and averaged $2600 \mathrm{~kg} \mathrm{DM} / \mathrm{ha}$. Pre-grazing yields showed a small but consistent response to $\mathrm{N}$ fertiliser, 
which reached significance in October-November $(+6 \%)$, was non-significant over December-January and February $(+5 \%)$, and was again significant in March $(+9 \%)$.

Total herbage accumulation was $6 \%$ higher for A1 than A3 (8.9 vs 8.4 t DM/ha; not significant). Most of this advantage was gained in spring (September to December) rather than summer-autumn (January to April). N-treated plots produced $9 \%$ more total herbage than did untreated plots (not significant). The silt loam soil grew on average over both lines $40 \%$ more total DM than did the peat (10.1 vs $7.2 \mathrm{t} \mathrm{DM/ha).}$

\section{Pasture botanical composition and tiller density}

The botanical composition of all plots was similar at both sites, apart from a small reduction in the white clover content of N-treated plots in December (19 vs $14 \%$ of DM, SED $\left.=2.6^{\mathrm{NS}}\right)$, a trend which continued into autumn (March). By March 1996, the ryegrass content of A1 plots was slightly less than in A3 (47 vs $55 \%$ of $\mathrm{DM}$ ), although this trend was not reflected in a decline in tiller density (2283 vs 1958 tillers $/ \mathrm{m}^{2}$, $\mathrm{LSR}=1.71^{\mathrm{NS}}$ ). A1 consistently increased tiller density in response to $\mathrm{N}$ fertiliser, but $\mathrm{A} 3$ did not. Tiller counts in fixed frames showed a large $(+44 \%)$ response to $\mathrm{N}$ from November 1995 to April 1996, mainly because A1 averaged $51 \%$ more tillers in $\mathrm{N}$-treated plots compared with $3 \%$ for $\mathrm{A} 3$.

\section{Leaf shear strength and leaf width}

The resistance of the leaves of A1 to shearing (shear strength) was higher than for A3 for both the tissue nearest the ligule $\left(6.21 \mathrm{vs} 5.91 \mathrm{~kg}, \mathrm{SED}=0.087^{*}\right)$ and the older tissue ( 5.08 vs $4.87 \mathrm{~kg}$, SED $=0.070^{*}$ ). The older tissue always tested lower.

The width of the youngest expanded leaves of both lines tended to be higher on the silt loam soil than on the peat, particularly for A1, causing a significant interaction (Table 4). $\mathrm{N}$ fertiliser did not significantly affect leaf shear strength or leaf width.

Table 4 Effects of soil type on the width $(\mathrm{mm})$ of the youngest expanded leaf of ryegrass lines $\mathrm{A} 1$ and $\mathrm{A} 3$ in April 1996. Measurements were made 3-6 $\mathrm{cm}$ from the leaf ligule.

\begin{tabular}{lccc}
\hline Line & Silt loam & $\begin{array}{c}\text { Soil type } \\
\text { Peat }\end{array}$ & Mean \\
\hline A1 & 3.621 & 3.171 & 3.396 \\
A3 & 3.252 & 3.179 & 3.216 \\
Mean & 3.437 & 3.175 & \\
\hline
\end{tabular}

SED for comparison of interaction means $=0.0804$

SED for comparison of line means $=0.0535$

\section{Discussion}

This experiment provides the first results showing that certain ryegrass lines are more inclined to "pull" than are others (Figures 1 and 2), implying that "plant factors" are involved in the pulling phenomenon, which plant breeders may be able to manipulate. We speculated that differences in leaf shear strength may result in different levels of pulling during grazing. This character was shown to be highly heritable and useful for selection purposes (Easton 1989), and breeding for low leaf strength can also improve feeding value (Henry et al. 1996).

Our findings were similar to those of Easton (1989) and showed that A1 had a higher leaf shear strength than did A3. The trend was also maintained after adjusting for leaf dry weight. Averaged over both soil types, A3 had narrower leaves than A1 (Table 4). Inoué et al. (1994) associated this characteristic with low leaf shear strength and a smaller cross-sectional area. We suggest these characteristics help explain why line A3 is more tolerant of pulling than is A1; the leaves of A3 are likely to break easier than those of A1 when grazed by cows, reducing the chances of clump removal from the pasture for A3, under particular climatic conditions. However, environment strongly influenced leaf width, with A1 tending to have a much broader leaf when grown on the silt loam soil than on peat. We can offer no explanation for this effect. Both lines tended to have wider leaves when grown on the silt loam (only significantly so for A1), which would have contributed to the greater accumulation of herbage on the silt loam soil than on the peat during Period 2.

The results confirm field and research (Tallowin 1985) observations that ryegrass pulling increased when soil moisture levels were low. Summer 1994-95 began with a 64-day dry period from mid-November to midJanuary. In contrast, dry weather in January 1996 was countered by rainfall $38 \%$ and $105 \%$ above average in December 1995 and February 1996, respectively, considerably reducing the level of drought stress on ryegrass. The fewer days without rainfall in summer 1995-96 compared with 1994-95, reduced the overall level of pulling of both lines; however, the trend for greater pulling in A1 plots was still evident (Table 3).

This work demonstrates a consistently higher level of pulling on the peat than on the silt loam soil, confirming farmer observations. This may reflect the lower soil strength (penetrometer resistance) reported by Houlbrooke (1996) for peat compared with silt loam soils.

Increased ryegrass pulling has also been correlated with $\mathrm{N}$ fertiliser use (Tallowin et al. 1986; Fulkerson et al. 1993). Our results tend to support these findings, 
but differences were never significant. The effect may be intensified by restricted root development where $\mathrm{N}$ fertiliser was applied (Mitchell \& Dickens 1979; Fulkerson et al. 1993), particularly when combined with a compacted soil layer near the soil surface. Houlbrooke (1996) demonstrated the presence of a compacted soil layer between 7 and $10.5 \mathrm{~cm}$ from the surface of the soils used in this study, and he estimated that $80 \%$ of the root dry weight (in $28 \mathrm{~cm}$ soil cores of $4.8 \mathrm{~cm}$ diameter) was in the top $7 \mathrm{~cm}$ of these soils. Charles (1979) also reported that soil compaction can reduce plant anchorage.

Prestidge et al. (1989) associated grass pulling with attack by shoot- and root-feeding insects such as Argentine stem weevil and grass grub; however, these were not considered important since the high-endophyte status of the lines would have minimised Argentine stem weevil damage, and grass grub is presently at a low level on No. 2 Dairy (R.A. Prestidge pers. comm.).

Despite more pulling losses on A1 than A3 plots, herbage accumulation was still higher on the former. This implies that A1 can compensate for pulling losses, at least in the short-term, although by the end of the second summer from sowing, the ryegrass content of A1 plots was below that of A3. However, on the peat (where pulling tended to be greatest for A1), A1 also tended to have a higher tiller density than did A3, reflecting a higher tillering capacity and ability to respond to N. Presumably over a longer time, and depending on the severity of drought in summer-autumn, the persistence of A1 relative to A3 would decline.

Even though A1 was capable of outyielding A3 in this trial, the likelihood of more pulling from this line means it will not be released as a commercial cultivar. This is because farmers associate pulling with losses in pasture production.

\section{ACKNOWLEDGEMENTS}

We thank Deanne Waugh, Bonita Koch and Heather Lagoda for technical assistance, and Wally Carter and staff of No. 2 Dairy for managing the trial pastures. We are grateful to Syd Easton (AgResearch) for providing the shear machine. Rhonda Hooper (Dairying Research Corporation) and Harold Henderson (AgResearch, Ruakura) provided statistical advice and carried out the data analyses. New Zealand Agriseeds Ltd provided the seed of the lines used and assisted with the funding of this trial.

\section{REFERENCES}

Anonymous. 1992. Perennial ryegrass pulling problem? Dairying today, February 1992.
Charles, A.H. 1979. Treading as a factor in sward deterioration. pp. 137-140. In: Charles, A.H.; Haggar, R.J. (eds). Changes in sward composition and productivity. Occasional symposium No. 10, British Grassland Society.

Cumberland, G.L.; Honore, E.N. 1970. An evaluation of Mangere ryegrass. New Zealand agricultural science, January 1970.

Easton, H.S. 1989. Variability of leaf shear strength in perennial ryegrass. New Zealand journal of agricultural research 32: 1-6.

Fulkerson, W.J.; Slack, K.; Moore, K.; Rolfe, C. 1993. Management of Lolium perenne/Trifolium repens pastures in the subtropics. I. Effect of defoliation interval, seeding rate and application of $\mathrm{N}$ and lime. Australian journal of agricultural research 44: 19471958.

Harris, S.L.; Thom, E.R.; Clark, D.A. 1996. Effect of high rates of nitrogen fertiliser on perennial ryegrass growth and morphology in grazed dairy pasture in northern New Zealand. New Zealand journal of agricultural research 39: 159-169.

Henry, D.A.; Macmillan, R.H.; Simpson, R.J. 1996. Measurement of the shear and tensile fracture properties of leaves of pasture grasses. Australian journal of agricultural research 47: 587-603.

Houlbrooke, D.J. 1996. Subsoiling and soil compaction effects on soil physical properties and pasture response. MSc thesis, University of Waikato. 155p.

Hughes, R.; Jackson, D.K. 1974. Impact of grazing management on sward survival. Journal of the British Grassland Society 29: 76.

Inoué, T.; Brookes, I.M.; John, A.; Hunt, W.F.; Barry, T.N. 1994. Effects of leaf shear breaking load on the feeding value of perennial ryegrass (Lolium perenne) for sheep. I. Effects on leaf anatomy and morphology. Journal of agricultural science 123: 129-136.

Matthew, C.; Black, C.K.; Butler, B.M. 1993. Tiller dynamics of perennation in three herbage grasses. Proceedings of the XVII International Grassland Congress 1993: 141-143.

Mitchell, C.H.; Dickens, R. 1979. Nitrogen fertilization and mowing height effects on tensile strength of bermudagrass sod. Agronomy journal 71: 10611062.

Prestidge, R.A.; van der Zijpp, S.; Gault, P. 1989. Effect of Argentine stem weevil on vigour of 'Grasslands Roa' tall fescue under dairying in the Waikato. New Zealand journal of agricultural research 32: 291297.

Singleton, P.L. 1991. Soils of Ruakura - a window on the Waikato. DSIR Land Resources Scientific Report No. 5. 122p. 
Tallowin, J.R.B. 1985. Herbage losses from tiller pulling in a continuously grazed perennial ryegrass sward. Grass and forage science 40: 13-18.

Tallowin, J.R.B.; Kirkham, F.W.; Brookman, S.K.E. 1986. Sward damage by sod-pulling - the effect of nitrogen. In: Frame, J. (ed.). Grazing. British Grassland Society. pp. 44-48.

Thom, E.R.; Sheath, G.W.; Bryant, A.M.; Cox, N.R. 1986. Renovation of pastures containing paspalum. 2. Effects of nitrogen fertiliser on the growth and persistence of overdrilled ryegrass. New Zealand journal of agricultural research 29: 587-598. 